\title{
PERCEPTIONS OF THE UNDERGRADUATE MEDICAL STUDENTS ABOUT THEIR ENGAGEMENT IN CURRICULUM DEVELOPMENT.
}

\footnotetext{
1. MBBS, MPH, MHPE Associate Professor Department of Community Medicine Khyber Girls Medical College Peshawar.

2. MBBS, MPH, MHPE Assistant Professor Department of Medical Education Khyber Girls Medical College Peshawar.

3. MBBS, MPH, PHD (Medical Education)

Assistant Professor Department of Medical Education \& Research

Khyber Medical University KPK.
}

Correspondence Address:

Dr. Naheed Mashood

House No.60, Street 9, Sector G-3

Phase-2, Hayatabad, Peshawar.

drnaheed1@yahoo.com

Article received on:

10/11/2019

Accepted for publication:

$21 / 03 / 2019$

\begin{abstract}
Alia Qazi', Naheed Mahsood ${ }^{2}$, Usman Mahboob ${ }^{3}$
ABSTRACT: The student's engagement in curriculum development is necessary and important, as this has direct effect on their academic performance. The positive feedback and criticism given by the students when engaged contributes to the development and changes in the curriculum. Objectives: To explore the perceptions of the under-graduate medical students about their engagement in the curriculum development. Study Design: A qualitative study. Setting: Two public and two private medical colleges in Peshawar, Khyber Pakhtunkhwa. Period: From $1^{\text {st }}$ January 2018 to $30^{\text {th }}$ June 2018. Material and Methods: Seven open ended questions were developed after literature search and were authenticated by three faculty members. After pilot testing, necessary changes were made in guiding questions. Four Focus Group Discussions (FGDs) were conducted with final year students, two from public and two from private medical colleges of Peshawar. The FGDs were audio recorded and transcribed verbatim. All transcripts were reviewed after each session and triangulation of data was done. Data was analyzed and themes were identified. Results: A total of 36 participants were included in FGDs. Four themes that emerged were "Increased interest of students in studies" indicating that the curriculum should be planned according to their priorities and co-curricular activities should be encouraged; "educational reforms" indicating that there is a need for improvement in the teaching style of the faculty,; "improved communication" indicating effective communication between the faculty and students; "favorable academic environment" indicating self-confidence of the students and good working relationship between students and faculty for producing conducive environment. Conclusion: The concept of engaging the students in planning the curriculum and extracurricular activities needs to be further structured. Academic workload and time constraints may be reduced when students are engaged in curriculum development.
\end{abstract}

Key words: Curriculum Development, Engagement, Perceptions, Public, Private Medical Institutes, Students, Undergraduate

Article Citation: Qazi A, Mahsood N, Mahboob U. Perceptions of the undergraduate medical students about their engagement in curriculum development. Professional Med J 2019; 26(11):1884-1891. DOI: 10.29309/TPMJ/2019.26.11.3092

\section{INTRODUCTION}

A curriculum is all about the teaching program, about the teachers' intention and how they proceed with it. ${ }^{1}$ Medical curriculum can only be effective means of learning for the students when it is written with the knowledge of their priorities, needs and abilities. ${ }^{2}$ The studies suggested that students must be made part of the committee who are designing, implementing, resourcing and evaluating the curriculum. ${ }^{3}$ Focusing on the student centered approaches the student involvement in curriculum development is now necessary and important, as awareness regarding the curriculum has direct effect on their academic performance. The positive feedback and criticism of the students will contribute to the development and changes in the curriculum. ${ }^{4,5,6}$

The surveys conducted were based on areas addressing the student's academics, faculty and student interaction and active collaborative learning. ${ }^{7}$ The areas identified from the literature for engagement of students in the curriculum can either be behavioral engagement in which the students will act in accordance to their wish like their punctuality and positive behavior. It can be emotional engagement where the students will show sense of belongings, development of interest and will enjoy their experience. Thirdly cognitive engagement when the students take 
interest in their learning, in this way they do more than their capacity and accept and enjoy the challenges. ${ }^{8}$

Engagement of students in curriculum development increases their interest and devotion to the studies giving good results in assessments and also contributes to the good reputation of the institute. $^{9}$

Student engagement is important both in academic and co-curricular activities ${ }^{10}$, when engaged they will take interest in the studies and their perspectives can generate good ideas regarding course contents and structure of the program. ${ }^{11,12,13}$

The purpose of this study is to explore the perceptions of the under graduate medical students about their engagement in curriculum development. Currently in our traditional curriculum there is no or very less engagement of students in curriculum. In Pakistan there are studies conducted on perceptions of medical students regarding the research ethics and clinical teachers as role model but there is limited literature on perceptions of their engagement in curriculum development and this area needed to be explored in both public and private sector colleges

\section{METHODOLOGY}

\section{Study Design}

It was a qualitative study. The study comprised four Focus Group Discussions conducted with final year undergraduate medical students of two public and two private medical colleges in Peshawar, Khyber Pakhtunkhwa. One FGD was carried out in each medical college forming a total of 04 FGD's with 09 students in each FGD; a total of 36 students. Purposive sampling technique was used because specific target were to be selected for the desired information. There was variation in participants based on their academic performance ranging from $\mathrm{A}$ grade to $\mathrm{C}$ grade and both genders included. Undergraduate medical students from final year MBBS, who were willing to participate and were present at the time of
FGD were included in the study.

The permission was taken from the Principals of medical colleges. The students were also apprised of the purpose of the study and informed consent was obtained from all participants and was ensured about the confidentiality of the responses. The FGDs were moderated and conducted by the principal investigator who was a qualified medical educationist and researcher. Each of FGD lasted 45 min to 1 hour. The assistant moderator helped in logistics and writing the key points as memos.

The gaps from the literature were identified and tried to develop the questions based on these gaps. Pilot testing showed that some questions were irrelevant or doubtful and were not contributing to the study results, some of the questions when asked were given the same responses by the participants so to avoid repetition some questions were removed. At the end only 07 questions were finalized.

Discussion points were transcribed from dicta phone. Moderator and assistant moderator reviewed all the transcripts after each session and coded the data under various headings. An analysis of text was done (word repetitions, keyindigenous terms, and key-words-in contexts) using an open coding technique. These codes were then shared with all authors of the study and any differences were sorted out and agreed upon by consensus. Any point that needed clarification was used as a guide for the next session. At the end of all sessions, four themes were emerged from this process, which were then reviewed by all authors till a consensus reached on themes. Data collection and data analysis was done simultaneously at the same time.

The final report was written and circulated to the participants for confirmation.

\section{RESULTS}

In first cycle of coding initial analysis was done by open coding, second cycle of coding was done to find out relationship by axial coding. Thematic analysis was performed through the process 
of coding in six phases to create meaningful patterns. These phases were: familiarization with data, generating initial codes, searching for themes among codes, reviewing themes, defining and naming themes, and producing the final report.

\begin{tabular}{|l|c|c|c|}
\hline $\begin{array}{c}\text { Public Sector } \\
\text { Medical Colleges }\end{array}$ & Girls & Boys & Age \\
\hline College 1 & 7 & 2 & $22-24$ \\
\hline College 2 & 9 & $\ldots \ldots .$. & $22-24$ \\
\hline \multicolumn{3}{|c|}{ Private Sector Medical colleges } \\
\hline College 1 & 6 & 3 & $22-24$ \\
\hline College 2 & 4 & 5 & $22-24$ \\
\hline Table-I. Gender and age of participants from public \\
and private colleges
\end{tabular}

A total of 30 open codes based on the important words used by the interviewees were identified. Words with similar meanings and implications were grouped together for the sake of conciseness.14 selective codes were identified,
13 sub themes and 04 themes.

A total of 36 participants in four FGD's discussed several issues which include improvement in the teaching style of the faculty, organized cocurricular activities, proper management of time, positive attitude of the faculty and the students, behavioral change, better attitude of faculty with students, effective interactions between the students and faculty, self-improvement through knowledge and skills, motivation to achieve goals, encouragement of the students, positive attitude of both the students and faculty, favoritism by the faculty, extra burden on students, faculty may feel threatened.

Four themes emerged as a result of this study were:

1. Increased interest of students in studies

2. Educational reforms

3. Improved communication

4. Favorable academic environment

\begin{tabular}{|c|c|c|c|c|c|}
\hline Abbreviation & $\begin{array}{c}\text { Codes from the } \\
\text { first coding cycle }\end{array}$ & Abbreviation & $\begin{array}{c}\text { Codes from the first } \\
\text { coding cycle }\end{array}$ & Abbreviation & $\begin{array}{c}\text { Codes from the first } \\
\text { coding cycle }\end{array}$ \\
\hline CT & Course taught & CS & Clinical subjects & P & Punctuality \\
\hline TP & Time period & AS & Assessment of students & IT & Improment in \\
\hline teaching
\end{tabular}

Table-II. List of codes given to the words used by interviewees, the codes from the initial or 1st coding cycle 


\begin{tabular}{|c|c|c|c|c|}
\hline $\begin{array}{l}\text { S } \\
\#\end{array}$ & Representative quotes from the interview & $\begin{array}{l}\text { Words used by } \\
\text { the interviewees } \\
\text { / categories } \\
\text { identified }\end{array}$ & $\begin{array}{l}\text { Codes } \\
\text { Used }\end{array}$ & $\begin{array}{l}\text { Number of times the } \\
\text { codes used by all } \\
\text { interviewees }\end{array}$ \\
\hline 1 & $\begin{array}{l}\text { I perceived curriculum as a document with chapters on basic } \\
\text { subjects only.(Participant } 3 \text { in FGD 1) } \\
\text { Curriculum is a document with clinical subjects only. (Participant } \\
6 \text { in FGD 1) } \\
\text { Curriculum is something which is related to field visits and } \\
\text { research projects.(Participant } 2 \text { in FGD 2) } \\
\text { Curriculum includes all academic activities in college. (Participant } \\
2 \text { in FGD 2) }\end{array}$ & Academic activities & $\begin{array}{l}\text { BS } \\
\text { CS } \\
\text { FV } \\
\text { RP }\end{array}$ & 48 \\
\hline 2 & $\begin{array}{l}\text { Extracurricular activities should be made part of the curriculum } \\
\text { and the students should be engaged in extracurricular activities. } \\
\text { (Participant } 5 \text { in FGD ) } \\
\text { Making extracurricular activities part of the curriculum will } \\
\text { increase their interest in extracurricular activities. (Participant } 3 \text { in } \\
\text { FGD 2) } \\
\text { By engaging students in curriculum development will also give } \\
\text { them an opportunity to streamline the extracurricular activities } \\
\text { as part of the curriculum, which is currently missing or totally } \\
\text { ignored. (Participant } 6 \text { in FGD 3) }\end{array}$ & $\begin{array}{l}\text { Extracurricular } \\
\text { activities (ECA) }\end{array}$ & ECA & 35 \\
\hline 4 & $\begin{array}{l}\text { Students should be engaged in the development of the courses } \\
\text { taught. (Participant } 3 \text { in FGD 4) }\end{array}$ & \multirow{2}{*}{ Educational reforms } & CT & 32 \\
\hline 5 & $\begin{array}{l}\text { Students should be engaged in the development of syllabus } \\
\text { section of the curriculum, as syllabus is directly related to their } \\
\text { studies, and will help them in improving their understanding of the } \\
\text { syllabus and learning capacity. (Participant } 4 \text { in FGD 2) }\end{array}$ & & SS & 30 \\
\hline 7 & $\begin{array}{l}\text { By engaging students in curriculum development will provide } \\
\text { them with an opportunity to interact with their teachers and peer. } \\
\text { (Participant } 2 \text { in FGD 2) } \\
\text { It will improve communication and working relationship of } \\
\text { students with their teachers and peers. (Participant } 3 \text { in FGD 4) } \\
\text { Engagement of students in curriculum development will } \\
\text { encourage team work and team building. (Participant } 6 \text { in FGD 4) }\end{array}$ & $\begin{array}{l}\text { Communication and } \\
\text { working skills }\end{array}$ & WR & 25 \\
\hline 8 & $\begin{array}{l}\text { Engaging the students in curriculum development will not only } \\
\text { build their understanding of the subjects but will also help in } \\
\text { managing the time for each subject according to their priority of } \\
\text { learning and understanding, such as giving more time to that part } \\
\text { of the curriculum which is difficult as compared to the one which } \\
\text { is easy to understand. This will also help them in improving their } \\
\text { time management skills. (Participant } 5 \text { in FGD 1) }\end{array}$ & Time management & TMS & 20 \\
\hline 9 & $\begin{array}{l}\text { By engaging students in such activities will put more burden on } \\
\text { students as they will find difficult to manage time for both the } \\
\text { activities, that is curriculum development and doing their studies. } \\
\text { (Participant } 3 \text { in FGD 1) } \\
\text { By engaging students in curriculum development along with their } \\
\text { studies, there is chance of missing out their regular classes and } \\
\text { clinical work in the hospital, resulting in negative effects on their } \\
\text { studies. (Participant } 4 \text { in FGD 2) }\end{array}$ & Negative effects & $\begin{array}{l}\text { BS } \\
\text { MRC }\end{array}$ & 20 \\
\hline
\end{tabular}




\begin{tabular}{|c|c|c|c|c|}
\hline 10 & $\begin{array}{l}\text { By coming into contact with the faculty will improve coordination between } \\
\text { students and the faculty, students will get more time to discuss different } \\
\text { matters, or issues related to curriculum and will also help the students in } \\
\text { building their self-confidence. (Participant } 2 \text { in FGD 3) }\end{array}$ & Motivation & MC & 16 \\
\hline 11 & $\begin{array}{l}\text { This participatory approach will develop interest of the students in } \\
\text { learning and understanding of the subjects, decreases the fear of studies } \\
\text { and making them more punctual in their studies. (Participant } 3 \text { in FGD 4) }\end{array}$ & Punctuality & $P$ & 15 \\
\hline 12 & $\begin{array}{l}\text { Interest in studies and punctuality will lead to better outcome in form of } \\
\text { good grades. (Participant } 4 \text { in FGD } 4 \text { ) }\end{array}$ & Good results & GR & 14 \\
\hline 13 & $\begin{array}{l}\text { By engaging the students in curriculum development will not only } \\
\text { improve their level of understanding of the curriculum but will give them } \\
\text { the sense of ownership for the curriculum with its deficiencies if any. } \\
\text { (Participant } 5 \text { in FGD 2) }\end{array}$ & Ownership & OS & 13 \\
\hline 14 & $\begin{array}{l}\text { If the students are fully engaged in the development of the curriculum, } \\
\text { then they can also comment or provide their feedback/suggestions on } \\
\text { the teaching methodologies in the curriculum. (Participant } 5 \text { in FGD 1) } \\
\text { The feedback/suggestions given by the students on teaching } \\
\text { methodologies can bring Improvement in teaching methodologies. } \\
\text { (Participant } 1 \text { in FGD 3) }\end{array}$ & Change in attitude & $\begin{array}{l}\text { FTM } \\
\text { IT }\end{array}$ & 08 \\
\hline 15 & $\begin{array}{l}\text { The students' interaction with faculty in curriculum development may } \\
\text { develop some friction due to difference of opinion on some point. } \\
\text { (Participant } 6 \text { in FGD 1) } \\
\text { Due to the friction caused by the difference of opinion between the } \\
\text { student and the faculty may damage the relationship between the } \\
\text { student and the faculty and confidence level of the students. (Participant } \\
3 \text { in FGD 3) } \\
\text { The faculty may become biased in the selection of the students and } \\
\text { chooses their favorite students only, this favoritism by the faculty can } \\
\text { sabotage the entire process and concept of curriculum development. } \\
\text { (Participant } 1 \text { in FGD 4) }\end{array}$ & $\begin{array}{l}\text { Student teacher } \\
\text { relationship }\end{array}$ & $\begin{array}{l}\mathrm{CL} \\
\mathrm{FF}\end{array}$ & 07 \\
\hline 16 & $\begin{array}{l}\text { The parents of the students may not allow their children to become part } \\
\text { of this activity, as they may perceive the fear of extra burden of work on } \\
\text { them, missing out of their regular classes and getting engaged into a } \\
\text { situation developed due to difference of opinion etc. (Participant } 6 \text { in FGD } \\
\text { 4) }\end{array}$ & $\begin{array}{l}\text { Interpersonal } \\
\text { relationship/ } \\
\text { Social issues }\end{array}$ & EB & 03 \\
\hline
\end{tabular}

\begin{tabular}{|c|c|c|c|}
\hline $\begin{array}{l}\text { Sr. } \\
\text { No }\end{array}$ & Themes & $\begin{array}{l}\text { Frequency of } \\
\text { Occurrence }\end{array}$ & Representative Quotes \\
\hline & $\begin{array}{l}\text { Increased interest of } \\
\text { students in studies }\end{array}$ & 32 & $\begin{array}{l}\text { "Students will take more interest in studies if they are engaged in curriculum } \\
\text { development from very beginning." } \\
\text { "Students will be manage all curricular and co-curricular activities more } \\
\text { enthusiastically if they are involved in each step of curriculum development." }\end{array}$ \\
\hline & Educational reforms & 27 & $\begin{array}{l}\text { "Educational reform is the need of the day. There is need of Improvement in the } \\
\text { teaching style of the faculty as well." }\end{array}$ \\
\hline & $\begin{array}{l}\text { Improved } \\
\text { communication }\end{array}$ & 22 & $\begin{array}{l}\text { "There will be effective communication between the faculty and students if } \\
\text { they are engaged in curriculum development." } \\
\text { "By engaging students in curriculum. There will be Improved coordination } \\
\text { and interpersonal relationship between faculty and students." }\end{array}$ \\
\hline & $\begin{array}{l}\text { Favorable academic } \\
\text { environment }\end{array}$ & 19 & $\begin{array}{l}\text { "Self-confidence of the students will be increased if they are involved in curriculum. } \\
\text { There will be good working relationship between students and faculty." } \\
\text { "There will be Improved learning and understanding of the curriculum if students are } \\
\text { engaged in curriculum development." }\end{array}$ \\
\hline \multicolumn{4}{|c|}{ Table-IV. Representative Quote's for Themes identified by participants } \\
\hline
\end{tabular}


All the participants were of the opinion that in the present scenario there is no engagement of the students in curricular and co-curricular activities so far as the planning is concerned. Most of the participants agreed that if engaged in such activities their interest will increase in studies which will enhance learning, bring improvement in the results and betterment in their attendance. They pointed out that proper time may be allocated to extracurricular activities on academic calendar. The students' perception was that they should also be engaged in assessment sections and given the opportunity to plan the assessment of the students. All the participants were of the opinion that by engaging in curriculum development their managerial and communication skills will improve. They will be able to communicate better with their faculty as well with their peers whether inside the college or outside in other medical colleges.

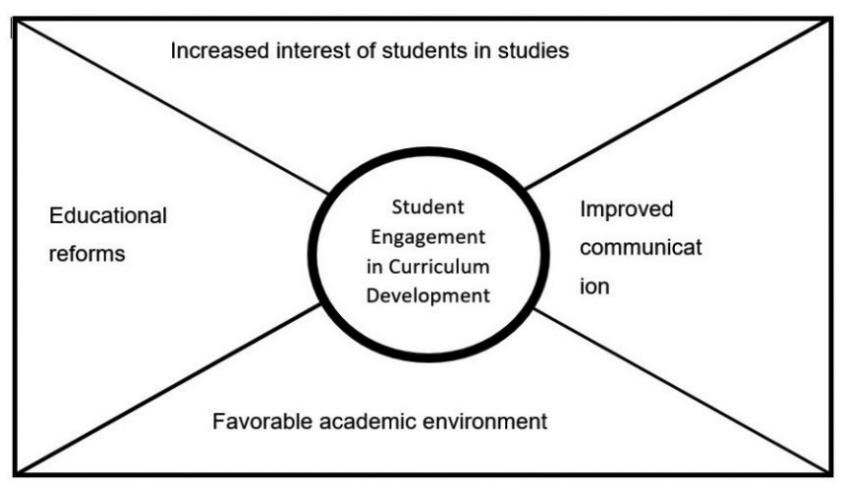

Figure-1. Thematic presentation of student's perception regarding their engagement in curriculum development

\section{DISCUSSION}

The results of this study are compared with different studies and researches of similar nature, the comparison revealed that the results evolved from this study are not very different from other studies and researches. The participants of this study were of the opinion that if given the opportunity to contribute to curriculum development, it would help them in building their interest in understanding and learning of the subjects, improve coordination with the faculty, develop ownership for the curriculum, improve self-confidence, improve grades in studies, thus improving overall academic performance and participation in the co-curricular activities.

\section{DISCUSSION ON THE THEMES IDENTIFIED}

\section{Increased Interest of Students in Studies}

Several qualitative studies and reviews from different corners of the world have reported similar concerns that engagement of students in curriculum development is of great importance in the sense that it will increase their interest in studies. ${ }^{14,15,16,17,18}$ Our study results also reveals that by engaging the students in curriculum development would increase their interest in studies, the international studies also suggested that in order to enhance learning, engagement of students in the process of curriculum development is must. ${ }^{19,20}$ The students become more active and can get good results. ${ }^{21}$

Other studies in comparison also suggest that the students who are more actively involved in studies \& learning are more focused..$^{22}$ Some of the literature pointed that the curriculum so far developed and delivered to the students is only limited to the faculty with no contribution or engagement of the students curriculum development. ${ }^{23}$

\section{Educational Reforms}

In other places of the world the student's engagement in the curriculum development is encouraged because the researchers believe that students are always interested and ready to experience new things and are open to suggestions. They can give better insight to their faculty and also how it can benefit the future students, ${ }^{2,5}$ The results of my study highlighted that students are career-oriented and are always interested and ready to take part in activities which can benefit them academically, socially and personally in developing their career. ${ }^{22}$ The review of previous research also support and acknowledge the findings of this study. ${ }^{23}$

Some of the participants of this study has intelligently pointed out that by engaging in such activities there may be extra burden on the students specially the representatives as they 
have to concentrate and manage their ongoing studies and also attending meetings related to curriculum development.

The students' commented that interaction with the faculty can help them improve their selfconfidence and coordination with their faculty and they are responsive to suggestions ${ }^{24}$, however there are chances of developing some friction between them and the faculty, in case if there is any debate or discussion on the difference of opinion.

\section{Better Communication}

In addition this study results also provide some additional information which include improvement in working relationship and coordination with the faculty and their peers, help them in improving their communication skills and learn to work as a team. ${ }^{2,5}$

Students can learn better if they participate in their own learning process. ${ }^{20}$ This is also in support of this study that the student can bring improvement in their knowledge and skills through participation into the process of curriculum development.

\section{Favorable Academic Environment}

A study regarding students' states that according to students' perceptions, problem based learning is not enough for adequate learning. To increase the understanding of the subject, spiral curriculum should be encouraged. ${ }^{20}$ this study participants also indicate towards innovative teaching methodologies, improved coordination and accommodative learning attitude of the faculty and the students.

Few of the studies highlighted the fact that students would love to take part in academic activities because they are career-oriented and they also know that such experience will benefit them not only at the personal level but also in building their academic career. ${ }^{24}$ My study also show similar results, that if the students are engaged in curriculum development they can contribute by providing feedback such inputs on academic discussion and interaction between the students' and faculty, establishes an environment of learning for both teachers and the students. ${ }^{22,23}$

\section{LIMITATIONS}

It was carried out in the public and private medical colleges of Khyber Pakhtunkhwa province only, therefore the results of the study cannot be generalized to medical colleges in other provinces of the country.

Another limitation of the study was that the information gathered was only from the students and the faculty perspective was not explored, therefore reflecting the perceptions of the students only. The information gathered from the faculty and their opinion on students' engagement in curriculum development could have enhanced the applicability of the research. Further research is needed to support the results of this study and to suggest effective interventions.

\section{CONCLUSION}

In this study a considerable number of students perceived that extracurricular activities if made part of the curriculum will not only help them in reducing their mental stress but will also help in increasing their interest in studies, they were also of the opinion that their engagement in curriculum development will help them in improving their interaction and coordination with the faculty, can provide feedback on teaching methodologies, improve their self-confidence and learn effective communication and time management skills, all leading to development of an enabling academic and learning environment.

There is a need for further research regarding perceptions of the students and their engagement in curriculum as there is limited research in Pakistan.

Copyright@ 21 March, 2019.

\section{REFERENCES}

1. Dent J, Harden RM. A practical guide for medical teachers: Elsevier Health Sciences; 2013.

2. Huppatz $C$. The essential role of the student in curriculum planning. Medical education. 1996; 30(1):913. 
3. MacCarrick G. A practical guide to using the World Federation for Medical Education (WFME) standards. WFME 1: mission and objectives. Irish journal of medical science. 2010; 179(4):483-7.

4. Bruner JS. The process of education. New York: Alfred A. Knop Inc. 1960.

5. Education alongside research as the mission of a medical, dental and veterinary school, Aspire recognition of excellence in student engagement in a Medical, Dental, Veterinary School, Criteria.

6. Artino Jr AR, La Rochelle JS, Dezee KJ, Gehlbach H. Developing questionnaires for educational research: AMEE Guide No. 87. Medical teacher. 2014; 36(6):46374.

7. Thomas PA, Kern DE, Hughes MT, Chen BY, editors. Curriculum development for medical education: a six-step approach. JHU Press; 2016 Jan 29.

8. Balfanz R, Herzog L, Mac Iver DJ. Preventing student disengagement and keeping students on the graduation path in urban middle-grades schools: Early identification and effective interventions. Educational Psychologist. 2007; 42(4):223-35.

9. AlFaris EA, Naeem N, Irfan F, Qureshi R, van der Vleuten C. Student centered curricular elements are associated with a healthier educational environment and lower depressive symptoms in medical students. BMC medical education. 2014; 14(1):192.

10. Scales PC. A portrait of young adolescents in the 1990s: Implications for promoting healthy growth and development. 1991.

11. Kuh GD, Hu S. The effects of student-faculty interaction in the 1990s. The Review of Higher Education. 2001; 24(3):309-32.

13. Parsons J, Taylor L. Improving student engagement. Current issues in education. 2011; 14(1).

14. Lauridsen DA. What are teachers' perceptions of the curriculum development process: The Ohio State University; 2003.
15. Tayem Yl, James H, Al-Khaja KA, Razzak RL, Potu BK, Sequeira RP. Medical students' perceptions of peer assessment in a problem-based learning curriculum. Sultan Qaboos University Medical Journal. 2015; 15(3):e376.

16. Clarke V, Braun V. Teaching thematic analysis: Overcoming challenges and developing strategies for effective learning. The psychologist. 2013; 26(2):120-3.

17. Davidson AL. Making and molding identity in schools: Student narratives on race, gender, and academic engagement: Suny Press; 1996.

18. Yazzie-Mintz E. Voices of students on engagement: A report on the 2006 high school survey of student engagement. Center for Evaluation and Education Policy, Indiana University. 2007.

19. Hickey WD, Sherman R. Readiness for active student engagement: Principals' perceptions related to the challenges of hands-on activities in a district of Belize. The Caribbean Teaching Scholar. 2013; 3(2).

20. Mo $Y$, Singh K, Chang M. Opportunity to learn and student engagement: A HLM study on eighth grade science achievement. Educational Research for Policy and Practice. 2013:1-17.

21. Fredricks JA. Eight myths of student disengagement: Creating classrooms of deep learning: Corwin Press; 2014.

22. Fredrick's, J. A., Blumenfeld, P. C., \& Paris, A. School engagement: Potential of the concept, state of the evidence. Review of Educational Research, 2004. 74(1), 59-109.

23. Parsons J, Taylor L. Improving student engagement. Current issues in education. 2011; 14(1).

24. Lauridsen DA. What are teachers' perceptions of the curriculum development process: The Ohio State University; 2003.

25. Joint (degree) Programs in south Eastern Europe student involvement in curriculum development. http://www.jointdegree.eu/index.php.

\begin{tabular}{|c|l|l|l|}
\hline \multicolumn{3}{|c|}{ AUTHORSHIP } & AND CONTRIBUTION DECLARATION \\
\hline Sr. \# & Author(s) Full Name & \multicolumn{1}{|c|}{ Contribution to the paper } & Author(s) Signature \\
\hline 1 & Alia Qazi & $\begin{array}{l}\text { AQ collected and analyzed the data, } \\
\text { and edited all drafts of the paper. } \\
\text { NM helped in generation of the idea, } \\
\text { and edited all drafts of the paper. } \\
\text { UM developed the methodology for } \\
\text { data collection and analysis and edited } \\
\text { the final draft of paper. }\end{array}$ \\
\hline 3 & Naheed Mahsood & \\
\hline
\end{tabular}

